\title{
EFEKTIVITAS PENDIDIKAN KESEHATAN SEKSUAL MELALUI MEDIA KOMIK DAN LEAFLET UNTUK MENINGKATKAN PENGETAHUAN DAN PERILAKU DALAM UPAYA MENCEGAH KEKERASAN SEKSUAL PADA ANAK DI SD NEGERI 12 PADANGSAMBIAN DENPASAR BARAT
}

\author{
Ni Kadek Wiwik Dwipayanti*,Komang Ekawati, Komang Ayu Kartika Sari \\ Program Studi Kesehatan Masyarakat Fakultas Kedokteran Universitas Udayana \\ *Email: wiwikdwipayanti@gmail.com
}

\begin{abstract}
ABSTRAK
Informasi mengenai kesehatan seksual sangat penting diberikan untuk anak- anak, agar mereka tahu akan kondisi tubuhnya, kondisi lawan jenisnya dan pemahaman untuk menghindarkan dari kekerasan seksual. Tujuan dari penelitian ini adalah untuk mengetahui media mana yang efektif digunakan untuk anak SD dalam meningkatkan pengetahuan dan perilaku tentang upaya pencegahan kekerasan seksual pada anak. Penelitian ini merupakan penelitian kuantitatif dengan desain Quasi Eksperiment Design dan teknik pengambilan subjek purposive sampling. Metode pengambilan data dilakukan dengan menggunakan kuesioner dan memberikan intervensi dengan menggunakan media komik dan leaflet. Subjek dalam penelitian ini adalah siswa kelas 5 SD dengan rentang umur 10-12 tahun sebanyak 86 responden. Dianalisis dengan uji T sampel berpasangan (paired sampel $T$ test) dan Independent $T$ test. Hasil yang diperoleh dari penelitian ini adalah pengetahuan responden meningkat setelah diberikan media komik sebanyak 12,98 dan perilaku siswa meningkat sebanyak 11,23. Adanya peningkatan rata-rata skor pengetahuan siswa SD sebanyak 9,60 dan peningkatan rata-rata skor perilaku siswa SD sebanyak 8,66 mengenai tindakan yang lakukan untuk mencegah terjadinya kekerasan seksual dengan menggunakan media leaflet. Kesimpulan adanya peningkatan pengetahuan dan perilaku siswa SD mengenai pencegahan kekerasan seksual pada anak menggunakan media komik maupun leaflet. Saran yang dapat diberikan adalah diharapkan kepada sekolah, orang tua, dan pemegang kebijakan yakni (P2TP2A) untuk memberikan informasi terkait pencegahan kekerasan seksual dan menggunakan media yang efektif seperti media komik dan leaflet.
\end{abstract}

Kata Kunci : Kekerasan seksual, Media komik, Media leaflet.

\begin{abstract}
Sexual health information is very important to be given to the children in order to give them knowledge on their body, their opposite gender body and to give understanding on how to prevent them from sexual violence. The aim of this research was to know which media that effective to be used to improve knowledge and behavior of student in one primary education in Bali on how to prevent sexual violence. This is a quantitative research using a Quasi Experiment design to understand the effectiveness of the comic and leaflet on improving knowledge of the research subject on sexual violence. Subject of the research was selected using purposive sampling and data gathered using questioners. Subject of the research were primary school's student year 5 with aged 10-12 years old with total number was 86 respondents. Data analysis using $\mathrm{T}$ test with paired sample and Independent $\mathrm{T}$ test. Finding indicated that the knowledge of the subject improves after given information on sexual violence using comic as media health promotion. There are 12.80 and the behavior of the children also improve to 11,23 . The mean score of knowledge of the students also increase as much as 8,66 on the action to prevent the occurrence of the sexual violence by using leaflet. To conclude, there is an increase in knowledge and behavior of the student about the prevention of the sexual violence among children using comic and leaflet as health promotion media. It is suggested that for schools, parents and District of Protection of Women and Children Right to give information on prevention of sexual violence using comic and leaflet as media education.
\end{abstract}

Keywords : Sexual Violation, Comic, leaflet

\section{PENDAHULUAN}

Informasi mengenai kesehatan seksual sangat penting diberikan untuk anak- anak, agar mereka tahu akan kondisi tubuhnya, kondisi lawan jenisnya dan pemahaman untuk menghindarkan dari kekerasan seksual. Namun di Bali media promosi kesehatan seksual untuk anak SD 
masih kurang. PKBI yang merupakan Lembaga Swadaya Masyarakat yang dilandasi kepedulian terhadap keselamatan ibu dan anak, hanya memiliki media permaianan edukatif dan materi yang menyesuaikan dengan tumbuh kembang anak, sedangan untuk di Dinas Pusat Pelayanan Terpadu Perlindungan Perempuan dan Anak (P2TP2A) belum memiliki media edukasi tentang kesehatan resproduksi dan kekerasan seksual untuk anak - anak. Oleh karena itu diperlukan media informasi kesehatan reproduksi kepada anak-anak untuk meningkatkan pengetahuan dan perilaku rencana tindakan mereka dalam menecegah terjadinya kekerasan seksual pada anak.

Salah satu kelompok anak-anak yang rentan menjadi korban kekerasan seksual adalah anak-anak yang duduk di bangku sekolah dasar (SD). Penelitian ini menyasar anak SD khususnya dalam rentang umur 10-12 tahun, dimana pada rentang usia ini, anak sudah mulai memasuki masa pubertas, anak - anak sudah mulai mengalami perubahan fisik dan mulai tertarik pada lawan jenisnya dikarenakan. Pada masa ini anak juga mulai masuk ke dalam dunia yang baru, mulai banyak berhubungan dengan orang-orang di luar keluarganya dan berkenalan dengan suasana dan lingkungan baru dalam kehidupannya (Andika, 2010)

Lokasi penelitian ini bertempat di Padangsambian Denpasar Barat yang dipilih karena di lokasi tersebut pernah terjadi kasus kekerasan seksual pada anak perempuan umur 13 Tahun (Tribun Bali, 18 Maret 2017). SD Negeri 12 Padangsambian Denpasar Barat merupakan salah satu SD di
Padangsambian yang belum penah diberikan informasi mengenai kesehatan reproduksi. Oleh karena itu peneliti ingin membuat suatu upaya pencegahan kekerasan seksual dalam bentuk edukasi melalui pemberian media komik dan leaflet di SD Negeri 12 Padangsambian Denpasar Barat. Tujuan dari penelitian ini adalah untuk mengetahui media mana yang efektif digunakan untuk anak SD dalam meningkatkan pengetahuan dan perilaku tentang upaya pencegahan kekerasan seksual pada anak.

\section{METODE}

Penelitian ini merupakan penelitian kuantitatif dengan desain Quasi Eksperiment Design dan teknik pengambilan subjek purposive sampling. Metode pengambilan data dilakukan dengan menggunakan angket dan memberikan intervensi dengan menggunakan media komik dan leaflet. Subjek dalam penelitian ini adalah siswa kelas 5 SD deangan rentang umur 10-12 tahun. Subjek dalam penelitian ini berjumlah 86 responden yang terbagi menjadi 2 kelompok, yakni kelompok A dan kelompok B.

\section{HASIL}

Perbandingan Pengetahuan dan Perilaku Siswa Sebelum dan Setelah Diberikan Media Komik dan Media Leaflet

Perbandingan pengetahuan siswa SD Negeri 12 Padangsambian Denpasar Barat dari sebelum diberikan penyuluhan dengan media komik dan media leaflet yang dilakukan dalam satu kali pengukuran setelah intervensi digambarkan melalui tabel berikut ini. 
Tabel 1. Perbandingan Pengetahuan kelompok media komik dan leaflet 1

\begin{tabular}{llll}
\hline \multirow{2}{*}{ Kelompok } & \multicolumn{2}{l}{ Pengetahuan (Mean) } & \multicolumn{1}{c}{} \\
\cline { 2 - 3 } & Pre & Post & value \\
\hline Media Komik & 83,09 & 96,03 & $<0.0001$ \\
Media Leaflet & 84,49 & 95,73 & $<0.0001$ \\
\hline
\end{tabular}

Tabel diatas menunjukkan secara keseluruhan nilai rata-rata post-test lebih tinggi dari nilai rata - rata pre-test pada media komik dan leaflet. Peningkatan pengetahuan pada pre-test dan post-test kedua media tersebut juga ditunjukkan melalui hasil paired $t$ test yang mendapatkan nilai $\mathrm{p}<0,0001$, sehingga nilai $\mathrm{p}<\alpha(0,05)$, yang berarti ada peningkatan bermakna antara nilai pengetahuan pre-test dan post-test menggunakan media komik maupun media leaflet.

Perbandingan perilaku siswa SD Negeri 12 Padangsambian Denpasar Barat dari sebelum diberikan penyuluhan dengan media komik dan media leaflet yang dilakukan dalam satu kali pengukuran setelah intervensi digambarkan melalui tabel berikut ini.

Tabel 2. Perbandingan perilaku kelompok media komik dan leaflet

\begin{tabular}{llll}
\hline \multirow{2}{*}{ Kelompok } & \multicolumn{2}{l}{ Mean Perilaku } & p value \\
\cline { 2 - 4 } & Pre & Post & \\
\hline Media Komik & 88,21 & 97,81 & $<0,0001$ \\
Media Leaflet & 88,22 & 96,88 & $<0,0001$ \\
\hline
\end{tabular}

Tabel diatas menunjukkan secara keseluruhan nilai rata-rata post-test lebih tinggi dari nilai rata - rata pre-test pada media komik dan leaflet. Peningkatan pengetahuan pada pre-test dan post-test kedua media tersebut juga ditunjukkan melalui hasil paired $t$ test yang mendapatkan nilai $\mathrm{p}<$ 0,0001, sehingga nilai $\mathrm{p}<\alpha(0,05)$, yang berarti bahwa ada peningkatan bermakna antara nilai pengetahuan pre-test dan posttest menggunakan media komik maupun media leaflet. 
Efektivitas Media Komik dan Leaflet dalam meningkatkan pengetahuan dan perilaku rencana tindakan anak dalam

Efektivitas media komik dan leaflet terhadap peningkatan pengetahaun dan $\begin{array}{lllll}\text { perilaku } & \text { siswa } & \text { SD } & \text { Negeri } & 12\end{array}$ dalam satu kali pengukuran setelah intervensi digambarkan melalui tabel berikut ini.

Tabel 5.7 Efektivitas Media Komik Dan Leaflet Terhadap Peningkatan Pengetahaun dan Perilaku Siswa SD Negeri 12 Padangsambian Denpasar Barat 1 upaya pencegahan kekerasan seksual Padangsambian Denpasar Barat yang dilihat

rata pre-test ke post-test. Pada media komik peningkatan nilai rata-rata perilaku sebanyak 9,60 terjadi dari pre-test ke post-test. Sama halnya dengan media leaflet, dimana media leaflet juga mengalami peningkatan perilaku dari nilai rata - rata sebanyak 8,66 dari pre-test ke post-test. Secara keseluruhan peningkatan tersebut sama antara kelompok media komik dan leaflet dilihat nilai $(\mathrm{p}>0,05)$ yang berarti sama-sama efektif memingkatkan pengetahuan atau perilaku tanpa memiliki perbedaan yang signifikan.

\section{PEMBAHASAN}

Perubahan Pengetahuan dan Perilaku siswa sebelum dan Setelah diberikan

\begin{tabular}{lllll}
\hline & \multicolumn{2}{l}{ Pengetahuan } & Perilaku \\
\cline { 2 - 5 } Kelompok & Mean & \multicolumn{2}{l}{ Mean } \\
& Selisih & & Selisih \\
& Post - & Post - & \\
& Pre & $\boldsymbol{P}$ & Pre & \\
& 12,94 & \multirow{2}{*}{0,27} & 9,60 & \\
Komik & 11,23 & & 8,66 & 0, \\
Leaflet & & & & \\
\hline
\end{tabular}
Intervensi dengan Media Komik

Tabel diatas menunjukkan bahwa media komik mengalami peningkatan pengetahuan hingga 12,94 dari nilai ratarata pengetahuan pre-test ke post-test. Sama halnya dengan media leaflet, dimana media leaflet juga mengalami peningkatan pengetahuan hingga 11,23 dari nilai rata -
Pengetahuan adalah hasil pengindraan manusia, atau hasil tahu seseorang terhadap objek melalui indera yang dimilikinya. Dengan sendirinya pada ,34 waktu pengindraan sehingga menghasilkan pengetahuan tersebut sangat dipengaruhi oleh intensitas perhatian dan persepsi terhadap objek. Pengetahuan seseorang juga dipengaruhi oleh berbagai hal yakni, pendidikan, sumber informasi, dan usia Notoatmodjo (2014).

Berdasarkan hasil penelitian yang telah dilakukan, nilai rata-rata pengetahuan siswa tentang pencegahan kekerasan seksual setelah mendapatkan intervensi dengan media komik menunjukkan 
peningkatan nilai rata - rata sebanyak 12,94 dengan nilai $\mathrm{p}<0,0001$. Hal ini sejalan dengan penelitian yang dilakukan oleh Marisa, (2014) tentang pengaruh pendidikan gizi seimbang terhadap pengetahuan dan siakp pada siswa SDN Bendungan di Semarang. Hasil penelitiannya menunjukkan bahwa pendidikan gizi melalui media komik gizi seimbang meningkatkan pengetahuan dan sikap tentang gizi seimbang secara bermakna.

Dari aspek biologi perilaku merupakan suatu kegiatan atau aktivitas organisme atau makhluk hidup bersangkutan. Aktivitas aktivitas tersebut dapat diamati secara langsung dan tidak dapat diamati secara langsung (Notoatmodjo, 2014). Menurut Skinner (1938) dalam Notoatmodjo (2014) seorang ahli psikologi merumuskan bahwa perilaku merupakan respons atau reaksi seseorang terhadap stimulus (rangsangan dari luar). Dengan demikian perilaku manusia terjadi melalui proses Stimulus Organisme - Respons, sehingga teori skinner ini disebut teori S-O-R. Stimulus yang dimaksud dalam penelitian ini adalah pemberian intervensi dengan menggunakan media komik. Pemberian informasi dengan menggunakan media komik diharapkan dapat meningkatkan pengetahuan responden sehingga dapat berdampak pada perubahan perilaku responden.

Berdasarkan hasil penelitian yang telah dilakukan, media komik berpengaruh terhadap perilaku siswa terkait pencegahan kekerasan seksual sebelum dan setelah diberikan intervensi dengan media komik menunjukkan peningkatan nilai rata - rata sebanyak 9,60 dengan nilai $\mathrm{p}<0,0001$. Media komik dapat memberikan pengaruh terhadap responden yang dalam hal ini terkait peningkatan perilaku, hal ini di dukung pernyataan dari Notoatmodjo (2014) dalam tindakan pencegahan jika terjadi kekerasan seksual pada anak. Perilaku pada hal ini merupakan perilaku tertutup, yakni perilaku yang terjadi bila respon terhadap stimulus belum dapat diamati oleh oranglain dari luar secara jelas. Menurut Notoatmodjo (2014) perilaku terbentuk dalam diri seseorang dari dua faktor utama yakni: stimulus merupakan faktor dari luar diri seseorang (faktor eksternal), dan respons merupakan faktor dari dalam diri orang yang bersangkutan (faktor internal). Faktor eksternal atau stimulus merupakan faktor lingkungan, baik lingkungan fisik, dan nonfisik dalam bentuk sosial, budaya, ekonomi, dan politik. Sedangkan faktor internal yang menentukan seseorang tersebut merespon stimulus dari luar adalah perhatian, pengamatan, persepsi, motivasi, fantasi, dan sugesti.

\section{Perubahan Pengetahuan dan Perilaku siswa sebelum dan Setelah diberikan Media Leaflet}

Media leaflet merupakan bentuk penyampaian informasi atau pesan - pesan kesehatan melalui lembaran yang lipat. Isi informasi dapat dalam bentuk kalimat maupun gambar atau kombinasi. Dalam hal ini peneliti memilih menggunakan leaflet, dikarenakan leaflet memiliki efektivitas yang sama dalam merubah sikap dimana berasarkan determinan perilaku adanya perubahan sikap akan mempengaruhi perilaku pencegahan.

Berdasarkan hasil penelitian, menunjukkan bahwa media leaflet dapat meningkatkan pengetahuan sebanyak 11,23 
siswa terkait informasi pencegahan kekerasan seksual dengan nilai $p<0,0001$ setelah diberikan intervensi. Hasil penelitian ini di dukung oleh penelitian yang pernah dilakukan oleh Kusuma (2014) terkait efektivitas media leaflet produk komisi penanggulangan AIDS kabupaten jember dalam pencegahan HIV/AIDS yang menunjukan bahwa media leaflet efektif dalam meningkatkan pengetahuan, sikap, dan praktik pencegahan HIV/AIDS. Hal tersebut karena media leaflet mampu mencukupi kebutuhan kegiatan promosi kesehatan di wilayah kerjanya, dan menjadikan media leflet sebagai pilihan utama bagi komisi penanggulangan AIDS sebagai media yang mampu meningkatkan perilaku pencegahan HIV/AIDS. Hal ini juga didukung oleh penelitian dari Budiyanto (2016) tentang Efektivitas Pemanfaatan Media Leaflet Dalam Meningkatkan Pengetahuan Dan Keterampilan Mencuci Tangan Dengan Sabun. Dari hasil penelitiannya menunjukkan bahwa media leaflet efektif meningkatkan pengetahuan mencuci tangan dengan sabun pada Mahasiswi Asrama Putri Sang Surya Universitas Muhamadiyah Malang.

Berdasarkan hasil penelitian, media leaflet dapat meningkatkan perilaku pencegahan siswa terkait informasi pencegahan kekerasan seksual pada anak dengan media komik menunjukkan peningkatan nilai rata - rata sebanyak 8,66 dengan nilai $p<0,0001$. Hal ini selaras dengan penelitian yang pernah dilakukan oleh Punia (2008) dalam penelitian Kusuma (2014) yang membandingkan efektifitas antara media booklet dan leaflet dalam meningkatkan pengetahuan, dan sikap terhadap pencegahan HIV/AIDS, dimana media booklet dan leaflet sama-sama efektif dalam meningkatkan pengetahuan dan sikap.

\section{Perbandingan Pengetahuan dan Perilaku anatara Kelompok Media Komik dan Leaflet}

Berdasarkan hasil penelitian ini, ditemukan bahwa media komik dan leaflet sama - sama memberikan perubahan terhadap peningkatan pengetahuan dan perilaku pada masing - masing kelompok hal ini di dukung oleh hasil nilai rata-rata media komik lebih tingggi meningkatkan pengetahuan siswa sebanyak $(12,94)$ dibandingkan dengan peningkatan pengetahuan dengan menggunakan media leaflet yakni sebanyak (11,23), namun bedasarkan hasil pengolahan data dengan menggunakan independent t-test menunjukkan hasil peningkatan media komik dan leaflet tidak menunjukkan perbedaan yang signifikan, diamana hasil tersebut menunjukkan bahwa media komik dan leaflet sama - sama dapat meningkatkan pengetahuan responden terkait pencegahan kekerasan seksual pada anak.

Kemudian berdasarkan hasil analisis data menunjukkan bahwa media komik lebih banyak meningkatkan perilaku tindakan pencegahan terkait kekerasan seksual yakni sebanyak $(9,60)$ dibandingkan dengan peningkatan pengetahuan media leaflet yakni $(8,66)$, namun hasil peningkatan media komik dan leaflet tidak menunjukkan perbedaan yang signifikan, diamana hasil tersebut menunjukkan bahwa media komik dan leaflet sama - sama dapat 
meningkatkan pengetahuan responden terkait pencegahan kekerasan seksual pada anak. Hasil penelitian ini menunjukkan bahwa kedua media berpengaruh terhadap peningkatan pengetahuan dan perilaku masing-masing kelompok dalam upaya pencegahan kekerasan seksual pada anak dan sama - sama signifikan dalam meningkatkan pengetahuan dan perilaku rencana tindakan responden terhadap pencegahan kekerasan seksual pada anak.

Penelitian ini sejalan dengan hasil penelitian sebelumnya yang dilakukan oleh Azrida (2015) tentang Efektifitas Media Cerita Bergambar Dan Leaflet Terhadap Pengetahuan dan perilaku Tentang Penyakit $\mathrm{Tb}$ di SD yang terdapat di Kota Medan, yang menunjukkan bahwa media cerita bergambar dan media leaflet merupakan media yang dapat meningkatkan pengetahuan dan perilaku anak sekolah dasar tentang pencegahan penyakit TB Paru.

\section{SIMPULAN}

Kesimpulan yang dapat diambil dari penelitian antara lain, adanya peningkatan rata-rata skor pengetahuan siswa SD sebanyak 12,98 mengenai pencegahan kekerasan seksual pada anak dengan menggunakan media komik. Adanya peningkatan rata-rata skor perilaku rencana tindakan siswa SD sebanyak 11,23 mengenai pencegahan kekerasan seksual pada anak dengan menggunakan media komik Adanya peningkatan rata-rata skor pengetahuan siswa SD sebanyak 9,60 mengenai tindakan yang lakukan untuk mencegah terjadinya kekerasan seksual dengan menggunakan media leaflet. Adanya peningkatan rata-rata skor perilaku tindakan pencegahan siswa SD sebanyak 8,66 mengenai tindakan yang lakukan untuk mencegah terjadinya kekerasan seksual dengan menggunakan media leaflet. Terakhir, apabila media komik dan leaflet tersebut dibandingkan maka media tersebut sama-sama efektif meningkatkan pengetahuan dan perilaku responden terhadap pencegahan kekerasan seksual pada anak.

\section{SARAN}

Diharapkan kepada sekolah, orang tua, dan pemegang kebijakan yakni (P2TP2A) untuk memberikan informasi terkait pencegahan kekerasan seksual dan menggunakan media yang efektif seperti media komik dan leaflet.

\section{DAFTAR PUSTAKA}

Andika, M. (2011). Dinamika Psikologis Kekerasan Seksual: Sebuah Studi Fenomenologi. Jurnal Psikologi Islam (JPI) Copyrigth (C) 2011 Lembaga Penelitian Pengembangan Psikologi dan Keislaman (LP3K). Vol 8 No. 2, Januari 2011 191-208.

Azrida (2015). Efektivitas Media Cerita Bergambar dan Leaflet Terhadap Pengetahuan dan Sikap Tentang Penyakit TB Paru di SD Negeri 060799 dan SD Negeri 060953. Universitas Sumatra Utara Medan

Budianto Krisno. (2016). Efektivitas Pemanfaatan Media Leaflet dalam Meningkatkan Pengetahuan dan Keterampilan Mencuci Tangan Dengan Sabun. Fakultas Keguruan dan ilmu 
Arc. Com. Health • Desember 2017

ISSN: 2527-3620

pendidikan di Universitas

Muhammadiyah Malang.

Marrisa. (2014). Pengaruh Pendidikan Gizi Melalui Komik Gizi Seimbang Terhadap Pengetahuan dan Sikap pada Siswa SDN Bendungan di Semarang. Universitas Diponogoro Semarang.

Notoatmodjo.(2012). Mtodologi Penelitian Kesehatan. Reneka Cipta - Jakarta

Notoatmodjo.(2014). Ilmu Perilaku KEsehatan. Reneka Cipta - Jakarta 